\title{
New Record of Black Turtle Chelonia mydas agassizii in High Latitudes of Eastern South Pacific Ocean
}

Benjamín Cáceres Murrie ${ }^{1,2}$, Anelio Aguayo Lobo ${ }^{1,3}$, Diana Scholfield ${ }^{2}$, Fabiola Arcos $^{2}$, Nicolás Muñoz García $^{1}$, Javier Cabello Stom ${ }^{4,5}$ and Jorge Acevedo ${ }^{2}$

1. Asociación de Investigadores del Museo de Historia Natural Rio Seco, Punta Arenas, Chile

2. Centro de Estudios del Cuaternario Fuego Patagonia y Antártica (CEQUA), Punta Arenas, Chile

3. Instituto Antártico Chileno (INACH), Punta Arenas, Chile

4. Universidad San Sebastián, Puerto Montt, Chile

5. Centro de Conservación de la Biodiversidad. Chiloé-Silvestre, Ancud, Chile

\begin{abstract}
A juvenile specimen of the black turtle, Chelonia mydas agassizii, was located in the shores of Cabo Tamar Island in the western entrance of the Strait of Magellan, Chile. A king crab angler found the specimen, and donated it to the Río Seco Natural History Museum's vertebrate collection for further studies and exhibition. Morphological measurements and a genetic analysis derived from an mtDNA fragment amplified and sequenced, suggest that this specimen corresponds to the species Chelonia mydas agassiizii and that it is closely related to the Galapagos Islands black turtle population. Possible influences of the El Niño Southern Oscillation phenomenon on this tropical species in the Eastern South Pacific Ocean are briefly discussed.
\end{abstract}

Key words: Magellan Strait, mitochondrial DNA, sea turtle, Testudines.

\section{Introduction}

The green turtle is one of the five species of sea turtles known to occur in Chilean waters [1-3]. Genus Chelonia, includes two subspecies, the eastern Pacific green turtle (also called black turtle) C. mydas agassizii (Boucort, 1868), considered to be a melanistic form of the genus Chelonia, and the green turtle C. mydas (Linnaeus, 1758). The former is normally distributed from Baja California to Peru including Revillagigedo and Galapagos Islands; however, vagrant individuals have been recorded in British Columbia and in Alaskan waters in the Northern hemisphere, as well as in Patagonian waters in the Southern hemisphere, nesting mainly on the coasts of Michoacán and Revillagigedo Islands (Mexico), Costa Rica's Pacific coast, and in the Galapagos Islands, Ecuador [4]. The green turtle, on

Corresponding author: Benjamín Cáceres, marine biologist and researcher at CEQUA foundation, research fields: marine vertebrates biology and ecology. the other hand, is found throughout all of the World's oceans, excepting Polar Regions [5-13].

In Chile, green turtles have been present since prehistorical times and modern records exist at least for the past two centuries [14]. Their presence has regularly been reported from Arica $\left(18^{\circ} 27^{\prime} \mathrm{S}\right)$ to Coquimbo $\left(29^{\circ} 58^{\prime} \mathrm{S}\right)$, where they feed mainly on seagrass, and to a lesser extent until Chiloé Island $\left(42^{\circ} 29^{\prime} \mathrm{S}\right)$ [1, 2, 15-22]. To date, there is only one previously published record for the green turtle at the extreme southern Chile waters. A 12-kg green turtle, with a $47-\mathrm{cm}$ long carapace, was found in the western sector of the Patagonian channels at Desolation Island $\left(52^{\circ} 57^{\prime} \mathrm{S}, 74^{\circ} 05^{\prime} \mathrm{W}\right)$, at the entrance of the Magellan Strait, on March the 12th of 1973 [23] (Fig. 1). Here, we record a new finding of the eastern Pacific green turtle in the southern tip of South America, updating the record list of this species in the southern region of Chile and providing a possible natal origin of the studied specimen. 


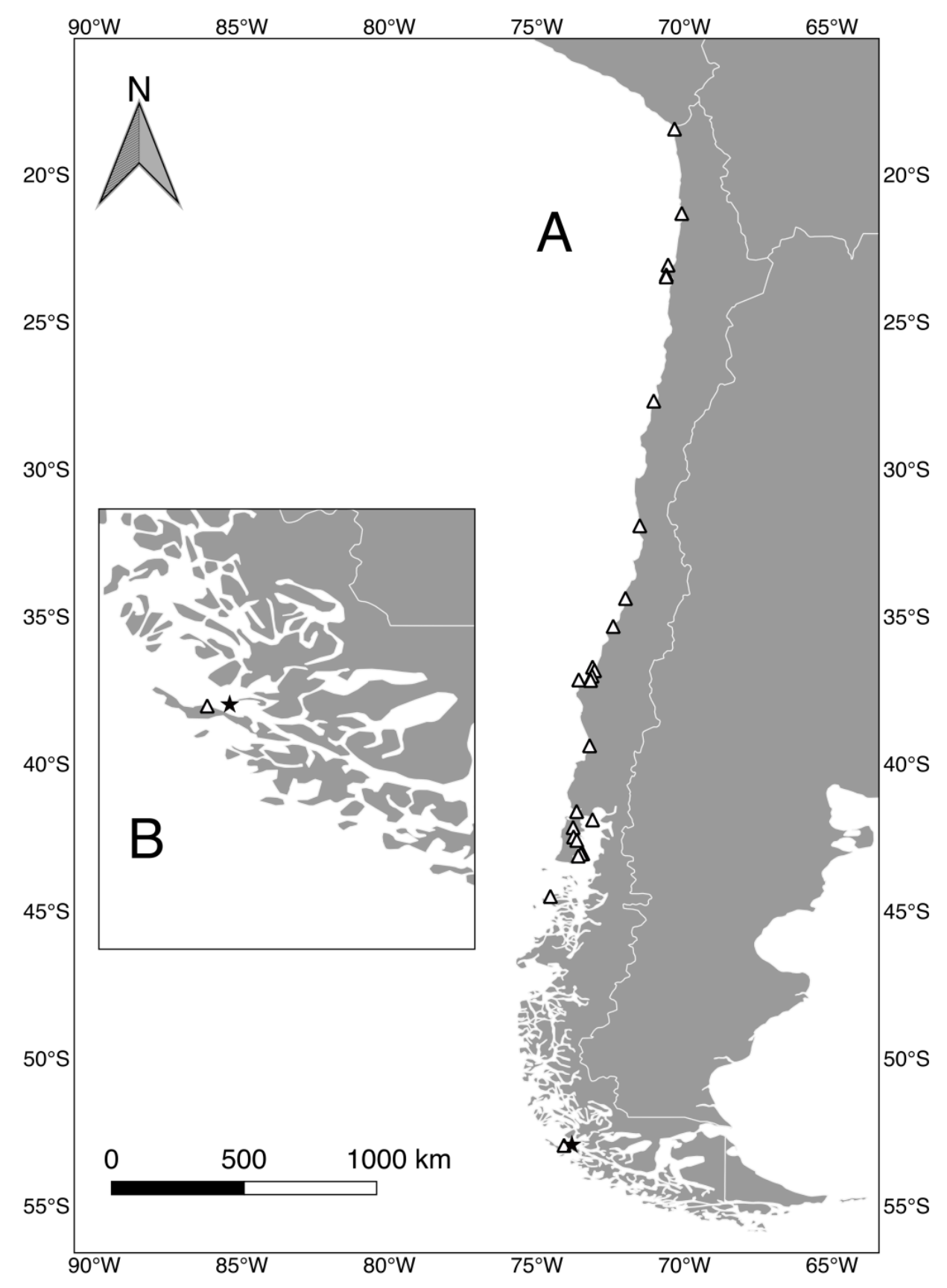

Fig. 1 Records of east Pacific green turtles (triangle) along the Chilean coast (A), and zoom of the region (B) where the new specimen was found at Tamar Island, Magellan Strait (star).

\section{Materials and Methods}

The specimen was found dead at Tamar Island $\left(52^{\circ} 56^{\prime} 00^{\prime \prime} \mathrm{S}, 73^{\circ} 49^{\prime} 00^{\prime \prime} \mathrm{W}\right)$ in July 30,2015 , by the fisherman Erwin Soto onboard "Helvecia Cuarta". It showed an advanced stage of decomposition, and was being consumed by a small flock of kelp gulls (Larus dominicanus). The right hind limb, lower jaws, intermaxillary and hyoid apparatus were missing, as well as scales on the head and scutes of the carapace and plastron. The carcass was donated to the zoology collection of the Río Seco Natural History Museum (MHNRS) under the MFSI-tes-0001 code, in order to prepare the skeleton for further studies and exhibition. 
Species identification was based on the skull shape, diagnostic patterns of bones of the palate, and shape of the carapace and entoplastron [24, 25]. Standard carapace length from the anterior-most point on the midline of the nuchal scute to the posterior-most tip of the last marginal (supracaudal or postcentral) scute, was measured in straightline (SCL) with calipers and curved (CCL) with a flexible tape measure, as well as the carapace width (SCW and CCW), respectively.

The presumptive $C$. mydas was also subjected to genetic analysis for taxonomic confirmation and identity of the species. DNA was extracted using a modification of the salting out method [26]. We amplified a 2380 bp fragment of the mtDNA control region with degenerate markers designed by Ref. [27]. The sequences of the primers were TCR5: 5'-TTGTACATCTACTTATTTACCAC-3 and TCR6: 5'-CAAGTAAAACTACCGTATGCC-3'. PCRs were performed in $25 \mu \mathrm{L}$ reactions containing $1 \times \mathrm{PCR}$ buffer, $2.5 \mathrm{mM} \mathrm{MgCl}, 0.2 \mathrm{mM}$ of each dNTPs, 0.8 $\mathrm{uM}$ of each primer and $1.25 \mathrm{U}$ GoTaq DNA polymerase (Promega). The PCR protocol consisted of an initial denaturation step $\left(95^{\circ} \mathrm{C}\right.$ for $3 \mathrm{~min}$ ) following by 40 cycles of $45 \mathrm{~s}$ at $95{ }^{\circ} \mathrm{C}$ (denaturing), $45 \mathrm{~s}$ at $59{ }^{\circ} \mathrm{C}$ (annealing) and $90 \mathrm{~s}$ at $72{ }^{\circ} \mathrm{C}$ (extension) and a final extension step of $10 \mathrm{~min}$ at $72{ }^{\circ} \mathrm{C}$. Quality and size of the PCR product were evaluated using $1 \%$ agarose gel with Gel-Red ${ }^{\mathrm{TM}}$ and PCR Markers $50 \mathrm{bp}$ Promega, and nucleotide sequences were determined for both strands of the PCR amplification products at the Macrogen (Korea) sequencing facility.

Available C. mydas sequences (eastern South Pacific $=17$; western South Atlantic $=5$ ) were downloaded from GenBank database (http://blast. ncbi. nlm. nih. gov/Blast .cgi) using the Blast procedure, to be included in the analysis for taxonomic confirmation and identity of the specimen (named as C_sp_CH). BIOEDIT Sequence Alignment Editor Program [28] and the ChromasPro program (version 1.7.7) were used to visualize, edit and align all sequences. Clustal W (in MacVector version 7.2; Accelrys, Madison, WI) was used for multiple alignments with the algorithm of Ref. [29]. We used a sequence of the loggerhead Caretta caretta (ID GenBank: DQ924967) as outgroup. All aligned sequences were uploaded at MacClade 4.0 program [30] to compare and evaluate the nucleotides composition, percentage of transitions and transversions, and number of polymorphic sites or their lengths. The most conserved and variable regions were explored in the sequenced regions. The relationship between the number of transitions and transversions was made comparing the sequences obtained from a pair, using the nucleotide substitution model of Ref. [31] with a bootstrap of 10,000 , and with substitution rate per site under the gamma parameter (5 categories, parameter 0.0500). Finally, a phylogenetic tree of haplotypes was generated using the Maximum-likelihood method with bootstrap method (1,000 replications) as implemented in the program MEGA 7.0 [32]. The best model was selected on the AIC value in JmodelTest 2.1.7 [33] and MEGA.

\section{Results}

Based on the state of decomposition, the death of the specimen is estimated at around 60 days (Fig. 2). A macroscopic visual inspection of the carapacial and plastron were without apparent epibionts, and no piece of plastic was found.

\subsection{Species Identification from Skeleton}

The skull (splanchnocranium) was small (about

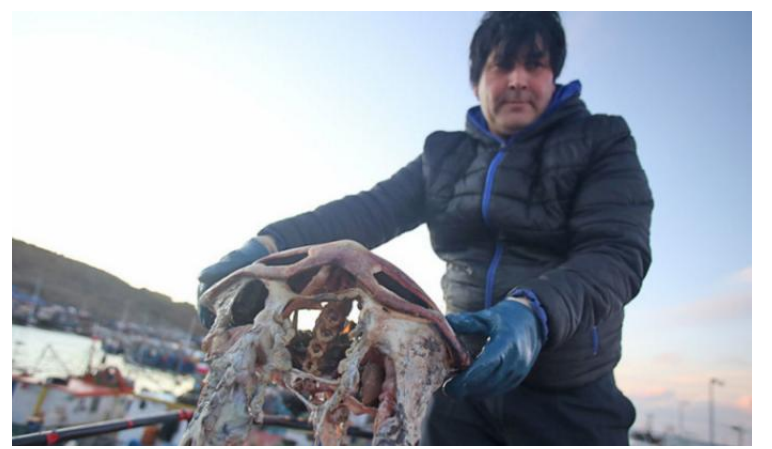

Fig. 2 Discovery of the turtle by the fisherman Erwin Soto at Tamar Island (a). 
$24.3 \%$ of SCL), rounded shape with a short snout and shallow parietal notches. The upper jaw has a smooth U-shaped outline. In the palate, a pair of ridges run parallel to the outer edge of the jaw between the margins of the upper jaw and the internal nares (Fig. 3).

The carapace is oval and elevated, with an outer margin slightly scalloped but not serrated. Its dorsal view is subcardiform and slightly emarginated over the neck and fore flippers; and the last third of the carapace has indentations between each marginal scute, typical of juvenile individuals. The carapace width attains $92 \%$ of its straight-line length (SCL) (Fig. 4 and Table 1).
The plastron has four pair of bones, epiplastron, hyoplastron, hipoplastron and xiphiplastron, and the distinctive elongated and narrow entoplastron with an arrow shape (Fig. 4).

\subsection{Genetic Analysis}

The mtDNA sequence of the studied turtle was nearly identical to the Chelonia mydas $(n=19)$ and Chelonia mydas agassizii $(n=2)$ sequences are available in GenBank. The phylogenetic tree grouped the haplotype of our specimen together with the Pacific clade (Fig. 5) and was compatible with the Galápagos haplotypes (Galap_KX499514 and AY540071).

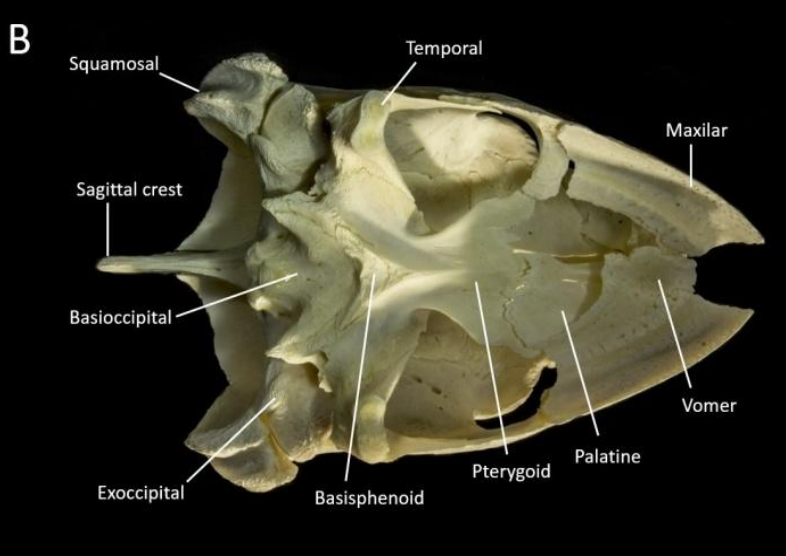

Fig. 3 Skull of the specimen at Tamar Island in lateral (A) and ventral (B) views.

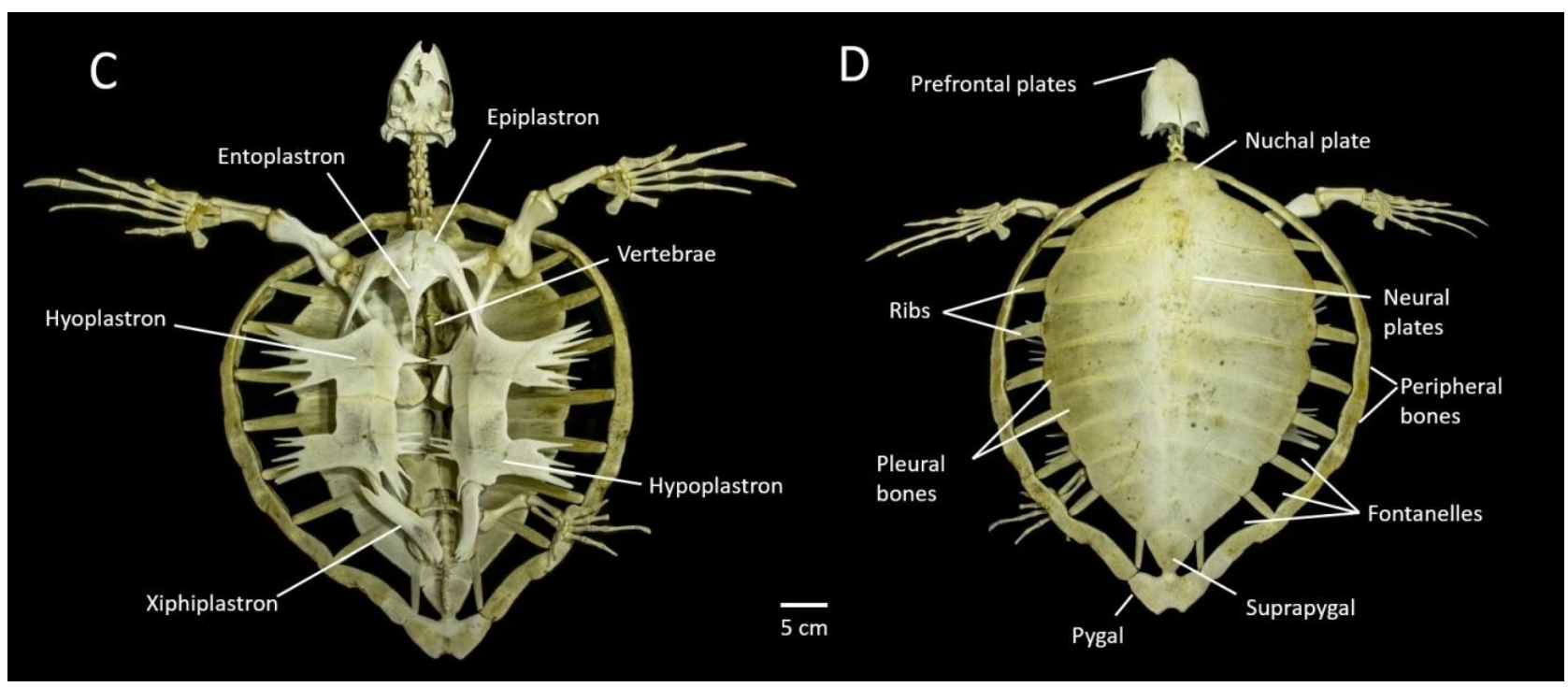

Fig. 4 Skeletal system of the specimen; (C) dorsal view and (D) ventral view. 


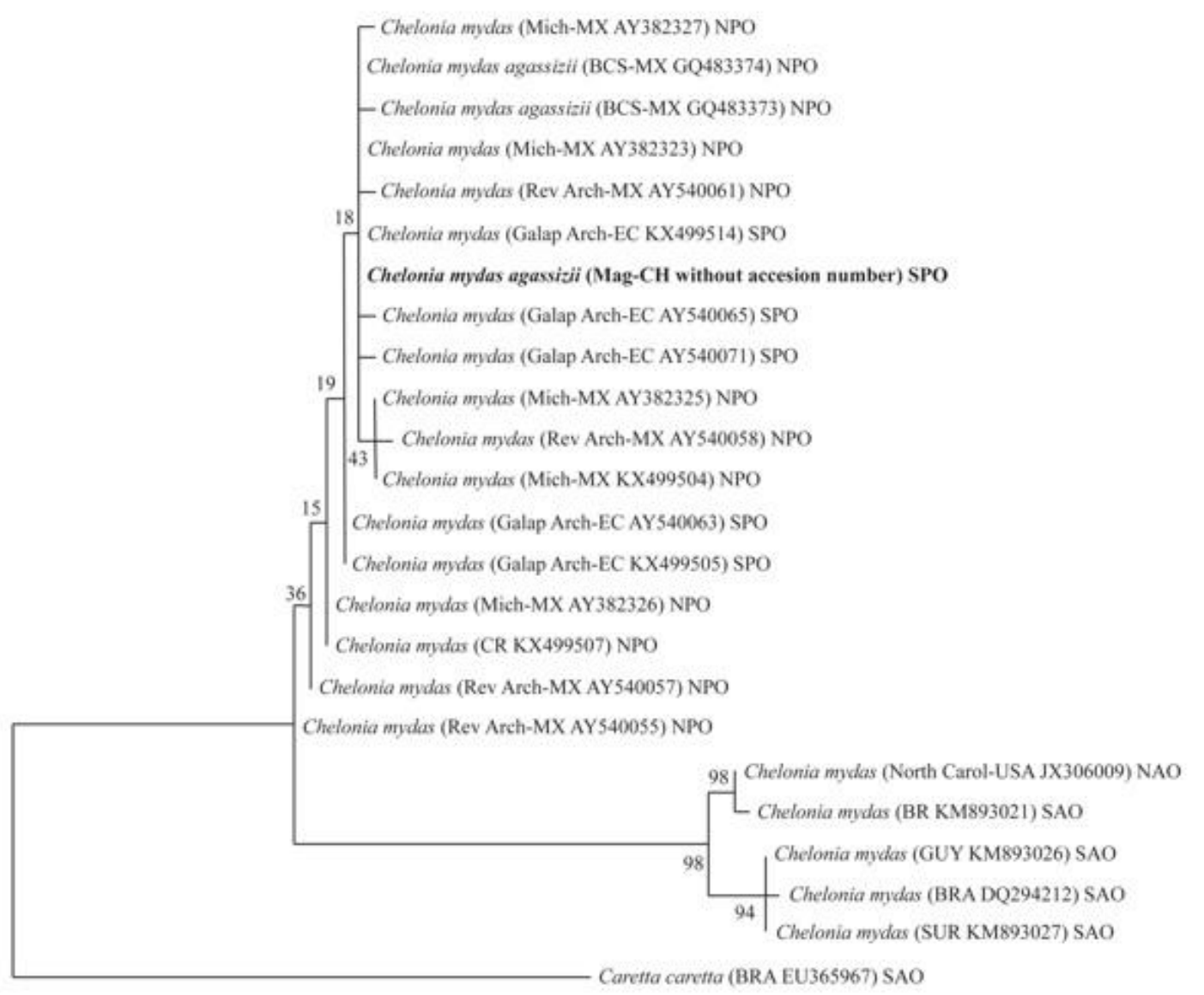

Fig. 5 Phylogenetic tree based on a 380 bp fragment of the mtDNA control region.

The phylogenetic tree is rooted on Caretta caretta. Nodal numbers are Bayesian posterior probability. Accession numbers of sequences derived from GenBank are shown in brackets. NAO: North Atlantic Ocean; SAO: South Atlantic Ocean; NPO: North Pacific Ocean; SPO: South Pacific Ocean; Mich: Michoacan; BCS: Baja California Sur; Rev Arch: Revillagigedo archipelago; Galap Arch: Galapagos archipelago; Mag: Magallanes; North Carol: North Caroline; MX: Mexico; EC: Ecuador; CH: Chile; CR: Costa Rica; USA: United States of America; BR: Brazil; GUY: Guyana; SUR: Suriname. The studied specimen is reported in bold.

Table 1 Summary of measurements of skull and carapace of the specimen found at Tamar Island in July 2015.

\begin{tabular}{ll}
\hline Measurements & Value $(\mathrm{mm})$ \\
\hline Standard length of skull & 124 \\
Standard width of skull & 79 \\
Standard carapace length (SCL) & 500 \\
Standard carapace width (SCW) & 460 \\
Minimum standard carapace length $\left(\mathrm{SCL}_{\min }\right)$ & 480 \\
Maximum standard carapace length $\left(\mathrm{SCL}_{\max }\right)$ & 525 \\
Curved carapace length (CCL) & 520 \\
Curved carapace width (CCW) & 480 \\
Minimum curve carapace length $\left(\mathrm{CCL}_{\min }\right)$ & 520 \\
Maximum curve carapace length $\left(\mathrm{CCL}_{\max }\right)$ & 530 \\
\hline
\end{tabular}

\section{Discusion}

The morphological characteristics of the skull of the specimen from Cabo Tamar match with those of the green turtle $C$. mydas, which is also reinforced by the results of the phylogenetic tree. Moreover, the nucleotide sequence of the studied turtle grouped in the haplotypes observed for the eastern Pacific green turtle, confirms that our specimen is $C$. mydas agassizii. In Chilean waters, eastern Pacific green turtle is present with most records clustered in northern regions and shows some evidence of movements of individuals south [1, 2, 14, 17, 19-22, $34,35]$, however, records in the extreme southern Chile are limited, with only one previously published record [23]. Our specimen was found only $19 \mathrm{~km} \mathrm{NE}$ of the previous record and represents the second 
southernmost record of an eastern Pacific green turtle in the Southern hemisphere. According to current evidence, the occurrence of this species in the southern tip of South America should be considered as accidental, although efforts to assess sea turtle in that high latitude are markedly reduced.

It is also interesting to note that the measurement of the carapace (SCL: $50.2 \mathrm{~cm}$ ) of our specimen was a juvenile [8, 36, 37], just like the specimen (SCL: 47 $\mathrm{cm})$ reported at Desolation Island [23]. These measures would be in line with the life stage reported for feeding areas in Peru [38, 39] and with the available size of measured specimens in Chilean waters (SCL mean: $49 \mathrm{~cm}$; [14]), indicating that most are juveniles or subadult individuals.

The green sea turtle is a highly migratory species in the eastern Pacific using different habitats during their life cycle [8, 36]. Origins of eastern Pacific green turtle individuals observed in Chilean waters have been assumed to come from the nesting population of Galápagos Islands [40], because multiple records of specimens tagged in Galápagos have been recaptured in Peruvian coastal waters [41]. Although no record exists of tagged eastern Pacific green turtles from Chilean coastal areas [14], this migratory pattern is supported by recent analyses of mtDNA from samples taken in the north of Chile (e.g., Ref. [22]). Our genetic analysis also grouped the Tamar Island specimen most closely with the Galápagos haplotypes (see Fig. 5), thus supporting this link between Galápagos and Chilean coasts, and extends the longest distance travelled by $C$. mydas agassizii (up to $\sim 5,900 \mathrm{~km}$ minimum travelling distance). The longest previously movement was reported for a tagged specimen that moved between Michoacan, Mexico and Buena Ventura, Colombia $(\sim 3,500 \mathrm{~km})[8]$.

Green turtles inhabit in tropical, subtropical, and warm temperate regions and rarely stray into cold waters [42]. In fact, most green turtles seek optimal sea water temperature near $18{ }^{\circ} \mathrm{C}[43,44]$. Even when the cause of death of the Tamar Island specimen is unknown, the sea surface temperature in June and July 2015 was below $10{ }^{\circ} \mathrm{C}$ and probably the specimen was cold-stressed and cannot survive to return to warmer waters. Under that sea surface temperature, cheloniid turtles are very close to their minimum thermal tolerance and cannot survive for extended periods [43-45]. Malnutrition and/or disease could have also been potential cause of death of the Tamar Island specimen; however, the advanced stage of decomposition does not allow us to provide details about the state of health, and as such, it is difficult to comment on the role of putative physiological problems or disease associated.

The presence of sea turtles in high latitudes has been associated to warm-water years [42]; however, the occurrence of Chelonia in, for example, Alaskan waters do not reflect a direct warm-water year connection [12]. Disorientation due to physiological anomalies and signs used in migration may be other possible cause; yet, as mentioned above, it is difficult to comment on the putative physiological problems or disease with our Tamar Island specimen. In Peru and north of Chile, it has been observed that the species expand their distribution and can be found in greater numbers during periods of oceanographic-atmospheric anomalies resulting from the El Niño Southern Oscillation [22, 46-48] and it is reasonable to expect that such events could affect their movements from foraging areas, but no conclusive evidence has been presented yet [22].

Among various physical and biological factors that might be involved, specimens found in both, 1973 (Desolacion Island) and 2015 (Tamar Island) at the Magellan Strait occurred during strong El Niño Southern Oscillation events (http://ggweather.com/enso/oni.htm), with maximum SST anomalies of $+2.1{ }^{\circ} \mathrm{C}$ and $+2.6{ }^{\circ} \mathrm{C}$ for $1972 / 1973$ and 2015/2016 El Niño events, respectively (http://origin.cpc.ncep.noaa.gov/products/analysis_mo nitoring/ensostuff/ONI_v5.php). Thus, from an 
oceanographic point of view, the incursion of superficial warm waters from tropical latitudes moving southward along the Chilean coastline during strong El Niño episodes, could explain the approach of both sea green turtles to the entrance of the Magellan Strait during 1973 and 2015, reflecting a direct warm-water year connection.

\section{Acknowledgments}

This manuscript was developed thanks to the project "BIP 30340972-0: Transferencias Científica y Tecnológica para el desarrollo Sustentable XII región, Gobierno Regional de Magallanes y Antártica". Authors would like to thank Mr. Erwin Soto for his valuable finding and donation to the Natural History Museum of Río Seco. We also thank Alfredo Prieto for giving the news of the finding, Alejandro Kusch for his help in transporting the specimen to the Museum's facilities, to the Museum staff, especially Miguel Cáceres for assisting on the cleaning and assembly processing of the skeleton, Sebastián Aspée, Gabriela Garrido, and Aymara Zegers for fabricating the box and its montage, and Gabriel Zegers for assisting with the map. Finally, we want to thank the directorate of the Centro de Estudios del Cuaternario Fuego Patagonia y Antártica (CEQUA), and its project and of the Instituto Antártico Chileno (INACH), for allowing us to work in this present contribution.

\section{References}

[1] Donoso-Barros, R. 1961. "Los reptiles del mar chileno." Museo Nacional de Historia Natural, Noticiero Mensual 58: 3 .

[2] Frazier, J., and Salas, S. 1982. "Tortugas Marinas en Chile.” Boletín del Museo de Historia Natural 39: 63-73.

[3] Álvarez-Varas, R., Flores, M., Demangel, D., García, M., and Sallaberry-Pincheira, N. 2015. "First Confirmed Report of Hawksbill Sea Turtle Eretmochelys imbricata in Nearshore Waters of Easter Island (Rapa Nui)." Revista de Biología Marina y Oceanografía 50 (3): 597-602. doi: 10.4067/S0718-19572015000400018.

[4] Eckert, K. L., Bjorndal, K. A., Abreu-Grobois, F. A, and Donnelly, M. 2000. “Técnicas de investigación y manejo para la conservación de las tortugas marinas." Grupo Especialista en Tortugas Marinas UICN/CSE Publicación No. 4: 1270.

[5] Carl, G. C. 1955. The green Turtle in British Columbia. Report of the Provincial Museum of Natural History and Anthropology. Victoria. British Columbia 1951: B77-8.

[6] Cliffton, K., Cornejo, D. O., and Felger, R. S. 1982. "Sea Turtles of the Pacific Coast of Mexico." In Biology and Conservation of Sea Turtles, edited by Bjorndal, K. A., Washington DC: Smithsonian Institution Press, pp. 199-209.

[7] Cornelius, S. E. 1982. "Status of Sea Turtles along the Pacific Coast of Middle America." In Biology and Conservation of Sea Turtles, edited by Bjorndal K. A., Washington, DC: Smithsonian Institution Press, pp. 211-9.

[8] Marquez, M. R. 1990. "Sea Turtles of the World. An Annotated and Illustrated Catalogue of Sea Turtle Species Known to Date." FAO Fisheris Synopsis No. 125, Vol. 11. Rome, FAO. p.81.

[9] Green, D. 1994. "Galapagos Sea Turtles: An Overview." In Proc. 13th Annual Symposium on Sea Turtle Biology Conservation. NOAA Tech Memo NMFSC-SEFSC-341, edited by Schroeder, B. A., and Witherington, D. E. Jekyll Island, GA, pp. 65-8.

[10] Karl, S. A., and Bowen, B. W. 1999. "Evolutionary Significant Units versus Geopolitical Taxonomy: Molecular Systematics of an Endangered Sea Turtle (genus Chelonia)." Conservation Biology 13: 99-999.

[11] Pritchard, P. 1999. "Status of the Black Turtle." Conservation Biology 13: 1000-3.

[12] Hodge, R. P., and Wing, B. L. 2000. "Occurrences of Marine Turtles in Alaska Waters: 1960-1998." Herpetological Review 31 (3): 148151.

[13] McAlpine, D. F., Orchard, S. A., and Sendall, K. A. 2002. "Recent Occurrence of the Green Turtle from British Columbia Waters." Northwest Science 76 (2): 185-8.

[14] Sarmiento-Devia, R. A., Harrod, C., and Pacheco, A. S. 2015. "Ecology and Conservation of Sea Turtles in Chile." Chelonian Conservation and Biology 14 (1): 21-33.

[15] Philippi, R. A. 1899. "Las Tortugas Chilenas.” Anales de la Universidad de Chile 104: 727-36.

[16] Quijada, B. 1916. "Catálogo sistemático de los reptiles chilenos i estranjeros conservados en el Museo Nacional de Historia Natural." Boletín del Museo Nacional de Historia Natural 9: 22-47.

[17] Yañez, P. 1951. "Vertebrados Marinos Chilenos." Revista de Biología Marina III (1 \& 2): 1-18.

[18] Donoso-Barros, R. 1966. Reptiles de Chile. Santiago: Ediciones Universidad de Chile.

[19] Bahamonde, N. 1972. "Límite austral de Chelonia mydas 
agassizi Bocourt, en el Pacífico Sur Oriental." Noticiario Mensual, Museo Nacional de Historia Natural 189: 9-10.

[20] Troncoso, J. F. 1988. "Registro de Chelonia mydas agassizii Bocourt, 1868, en el litoral de la VIII Región, Chile." Comunicaciones del Museo Regional de Concepción 2: 29-30.

[21] Ibarra, H., and Ortiz, J. C. 1990. "Nuevos registros y ampliación de la distribución geográfica de algunas tortugas marinas de Chile." Boletín de la Sociedad de Biología de Concepción 61: 149-51.

[22] Veliz, D., Salinas, P., Sielfeld, W., Contreras, D., Azócar, C., Tobar, M., and Gallardo, J. 2014. "Estudio poblacional y genético de la tortuga Chelonia mydas agassizii (Sauria: Cheloniidae) en la Playa Chinchorro, Arica, Chile." Revista de Biología Marina y Oceanografía 49 (3): 589-93.

[23] Guzmán, L., and Campodónico, I. 1973. "Presencia de Chelonia mydas agassizii Bocourt en Magallanes." Anales del Instituto de la Patagonia 4: 339-41.

[24] Frick, M. G. 1996. "A Guide for the Identification of Stranded Sea Turtle: The Eastern United State and the Gulf of Mexico." Special Publication No 4, SavannahScience Museum, Inc. p. 27.

[25] Wyneken, J. 2001. "The Anatomy of Sea Turtles.” U.S. Department of Commerce NOAA Technical Memorandum NMFS-SEFSC-470, p. 172.

[26] Aljanabi, S. M., and Martínez, I. 1997. "Universal and Rapid Salt-Extraction of High Quality Genomic DNA for PCR-Based Techniques." Nucleic Acids Research 25: 4692-3.

[27] Norman, J. A., Morits, C., and Limpus, C. J. 1994. “Mitochondrial DNA Control Region Polymorphism's: Genetic Markers for Ecological Studies of Marine Turtles." Molecular Ecology 3: 363-73.

[28] Hall, T. A. 1999. BioEdit: a user-friendly biological sequence alignment editor and analysis program for Windows 95/98/NT. Nucleic Acids Symposium Series 41: 95-8

[29] Thompson, J. D., Gibson, T., Plewniak, F., Jeanmougin, F., and Higgins, D. 1997. The CLUSTAL_X Windows Interface: Flexible Strategies for Multiple Sequence Alignment Aided by Quality Analysis Tools, Nucleic Acids Research 25 (24): 4876-82.

[30] Madison, D. R., and Madison, W. P. 2011. Software MacClade, vers. 4.

[31] Tamura, K., and Nei, M. 1993. "Estimation of the Number of Nucleotide Substitutions in the Control Region of Mitochondrial DNA in Humans and Chimpanzees." Molecular Biology Evolution 10 (3): 512-26.

[32] Kumar, S., Stecher, G., and Tamura, K. 2016. MEGA7: Molecular Evolutionary Genetics Analysis version 7.0 for bigger datasets.

[33] Posada, D. 2008. "ModelTest: Phylogenetic Model Averaging." Molecular Biology Evolution 25 (7): 1253-6.

[34] Donoso-Barros, R. 1970. "Catálogo herpetológico chileno." Boletín del Museo Nacional de Historia Natural 31: 49-124.

[35] Troncoso J. F. 1990. "Nuevo registro de Chelonia mydas agassizii Bocourt, 1868, en el Pacífico sur, VIII Región, Chile." Comunicaciones del Museo Regional de Concepción 4: 61.

[36] Hirth, H. F. 1997. "Synopsis of the Biological Data on the Green Turtle, Chelonia mydas, (Linnaeus, 1758)." Report No. 97, US Fish and Wildlife Service, Silver Spring, MD.

[37] Arthur, K., and Balazs, G. H. 2008. "A Comparison of Immature Green Turtle (Chelonia mydas) Diets among Seven Sites in the Main Hawaiian Islands." Pacific Science 62: 205-17.

[38] Velez-Zuazo, X., Quiñones, J., Pacheco, A. S., Klinge, L., Paredes, E., Quispe, S., and Kelez, S. 2014. "Fast Growing, Healthy and Resident Green Turtles (Chelonia mydas) at Two Neritic Sites in the Central and Northern Coast of Peru: Implications for Conservation." PLoS ONE 9 (11): e113068.

[39] Quiñones, J., García-Godos, I., Llapapasca, M., Van Ordt, F., and Paredes, E. 2015. "The Black Sea Turtle (Chelonia mydas agassizii) at Lobos de Tierra Island, Northern Peru: High Densities in Small Areas." South American Journal of Herpetology 10 (3): 178-86.

[40] Frazier, J. 1990. "Marine Turtles in Chile: An Update." In Proceedings of the Tenth Annual Workshop on Sea Turtle Biology and Conservation, 20-24 February 1990, Hilton Head, South Carolina, edited by Richardson, T. H., Richardson, J. I., and Donnelly, M. NOAA Technical Memory NMFS-SEFC. St. Petersburg, pp. 39-42.

[41] Green, D. 1984. "Long-Distance Movements of Galápagos Green Turtles.” Journal of Herpetology 18 (2): 121-30.

[42] Eckert, K. L. 1993. "The Biology and Population Status of Marine Turtles in the North Pacific Ocean.” U.S. Dept. Commerce, NOAA Technical Memorandum. NMFS-SWFSC-186.

[43] Mrosovsky, N. 1980. "Thermal Biology of Sea Turtles." American Zoologist. 20: 543-7.

[44] Schwartz, F. J. 1978. "Behavioral and Tolerance Responses to Cold Water Temperatures by Three Species of Sea Turtles (Reptilia, Cheloniidae) in North Carolina.' Florida Marine Research Publications 33: 16-8.

[45] Davenport, J. 1997. "Temperature and the Life-History Strategies of Sea Turtles." Journal of Thermal Biology 22: 479-88.

[46] Aranda, C., and Chandler, M. V. 1989. "Las Tortugas 
158 New Record of Black Turtle Chelonia mydas agassizii in High Latitudes of Eastern South Pacific Ocean

Marinas del Perú y su situación actual." Boletín de Lima 62: 77-86

[47] Quiñones, J., González, V., Zeballos, J., Purca, S., and Mianzan, H. 2010. "Effects of El Niño-driven Environmental Variability on Black Turtle Migration to
Peruvian foraging Grounds." Hydrobiologia 645: 69-79.

[48] Castro, J., De la Cruz, J., Ramírez, P., and Quiñones, J. 2012. "Captura incidental de tortugas marinas durante El Niño 1997-1998, en el norte del Perú.” Latin American Journal of Aquatic Research 40 (4): 970-9. 